\title{
SERUM IODINE IN HYPERTHYROIDISM, WITH PARTICULAR REFERENCE TO THE EFFECTS OF SUBTOTAL THYROIDECTOMY ${ }^{1}$
}

\author{
By ALEXANDER W. WINKLER, DOUGLAS S. RIGGS, KENNETH W. \\ THOMPSON, AND EVELYN B. MAN \\ (From the Departments of Medicine, Psychiatry, and Surgery, Yale University School of \\ Medicine, and from the Medical and Surgical Services of the New Haven \\ Hospital, New Haven)
}

(Received for publication December 3, 1945)

The concentration of precipitable ${ }^{2}$ iodine in serum is a sensitive index of concentration of circulating thyroid hormone ( 1 to 7 ). The level of precipitable iodine is characteristically elevated in untreated hyperthyroidism (1 to 3,6$)$ and tends to fall after iodine medication and after thyroidectomy (3). In the present study the changes following treatment were analyzed with special reference to the development of abnormally low or high levels of precipitable iodine at various intervals after operation.

\section{MATERIAL AND METHODS}

Whenever possible, total or precipitable iodine concentration in serum was measured before any treatment was given. Iodine medication in the form of strong solution of iodine U.S.P., 5 drops 3 times a day, was then given until the day of subtotal thyroidectomy, when it was discontinued. In a few instances the measurement of serum precipitable iodine concentration was repeated just before operation. At various intervals after subtotal thyroidectomy the concentration of iodine in serum was again determined. In many instances, including all those in whom the subtotal thyroidectomy was done prior to 1940 , postoperative determinations alone were made. Only patients in whom the diagnosis of hyperthyroidism was established by a characteristic clinical picture and by subsequent pathological examination of the gland removed at operation are included. Basal metabolic rate and concentration of cholesterol in serum were also followed postoperatively.

In the years during which these observations were made (1940 to Oct., 1944) the technical character of the operation of subtotal thyroidectomy in the New Haven Hospital was planned by one of the authors (K. W. Thompson). The majority of the operations were performed by him, or done under his direction by the resident

\footnotetext{
1 Aided by grants from the Fluid Research Fund of the Yale University School of Medicine.

2 The "precipitable" iodine includes all iodine which is precipitated along with the serum proteins. It is the same fraction which is sometimes referred to as "protein bound" or "hormonal" iodine.
}

surgeon. A rather complete standardized thyroidectomy 3 was carried out in the belief that a radical operation would reduce the incidence of recurrent hyperthyroidism, which is regarded as a highly unfavorable outcome. About 140 operations for subtotal thyroidectomy were performed during this period. An initial determination of the serum total or precipitable iodine was made in 87 instances, and of the whole blood iodine in 26 more. At some time during the first 6 months after operation the serum iodine determination was repeated one or more times in 60 of these cases, which were selected more or less at random. After 6 months serum iodine determinations were made in only 32 of these cases.

There were included also 51 additional cases whose operation had been done before 1940; in about half of these cases the subtotal thyroidectomy had been done in the New Haven Hospital before 1940. Unlike the studies during the first 6 postoperative months, many of these later studies were made because of suspected hypothyroidism or recurrent hyperthyroidism.

Analyses of serum precipitable iodine were made by the method of Man et al. (3), adapted to the procedure of Riggs and Man (8) for whole blood iodine using permanganate acid ashing. Some values of the serum total iodine are included; normally in the absence of iodine medication these do not exceed the corresponding precipitable values by more than one gamma pet cent (9). In a few instances (those analyses made prior to March,

3 The procedure was as follows: the anesthesia was basal avertin, supplemented by cyclopropane and local procaine (1 per cent without epinephrine). In the majority of the cases the parathyroid glands, especially those at the lower poles, and the recurrent laryngeal nerves were visualized, in order to avoid their injury. The right lobe of the gland was totally removed in all cases except those in which it was unduly adherent or did not separate easily from the recurrent nerve; when this occurred a thin fringe of gland was allowed to remain. All of the lingula and the isthmus were removed together with the left lobe, save for a small piece of the left lobe lying over the recurrent nerve. The amount of gland allowed to remain measured approximately $2 \times 1.5 \times 0.5$ $\mathrm{cm}$. There were usually small fringes of gland of very small size at the upper and lower poles because the polar vessels were usually divided at the level of the capsule of the gland. 
1941) serum total iodine values were calculated from whole blood values by dividing the latter by the factor 0.6 (5). Cholesterol was determined by methods previously described (10).

\section{RESULTS}

\section{Concentration of iodine in serum before treatment 4}

The total iodine concentration was determined in sera from 50 untreated cases of hyperthyroidism, and the precipitable iodine concentration in sera from 37 other untreated cases. The confidence limits indicated that 95 per cent of the values might be expected to fall between 28.74 and 6.63 gamma per cent and 90 per cent between 25.48 and 7.47 gamma per cent. In the actual distribution 3 values fell below 8.4 gamma per cent (5.8, 4.9, and 7.0) and 3 values above 25.0 gamma per cent $(30.1,36.5$, and 55.1). The 2 lowest values were from patients with mild hyperthyroidism, who may have been in spontaneous remission, but who nevertheless came to operation within a few weeks. The 3 high values were found in cases of severe hyperthyroidism which were not otherwise remarkable.

A positive correlation existed between concentration of iodine in serum and basal metabolic rate in this series $(P<0.01)$, but it was not close.

4 The authors are indebted to Miss Barbara Bartels and Dr. Chester Bliss for this statistical analysis. Although the frequency distributions of the arithmetic values of both precipitable and total sets were somewhat askew, the distribution of their logarithms appeared normal by a graphic test. The logarithmic values were therefore subjected to statistical analysis, and the final results translated back into arithmetic terms. The mean value $(\bar{x})$ for concentration of total iodine was 13.76 , standard error of the mean $(s \bar{x}) \pm 2.26$ gamma per cent; the mean value for concentration of precipitable iodine was $13.85, s \bar{x} \pm$ 2.63 gamma per cent. (The standard errors were calculated by an approximate formula.) Because of a good agreement between the variances of the two sets (as tested by Bartlett's chi square test) and because of the good agreement of the means themselves, the entire 87 values could be pooled for estimation of confidence limits. The mean value for the entire group was $13.80, s \bar{x} \pm 1.71$ gamma per cent. The confidence limits were calculated by the approximate formula $\bar{x} \pm t s \sqrt{\frac{N+1}{N}}$, where $\bar{x}$ is the mean, $t$ (for the desired level of probability and the degree of freedom) is derived from Fisher's Tables, $s$ is the standard deviation, and, $N$ is the number of values in the series.

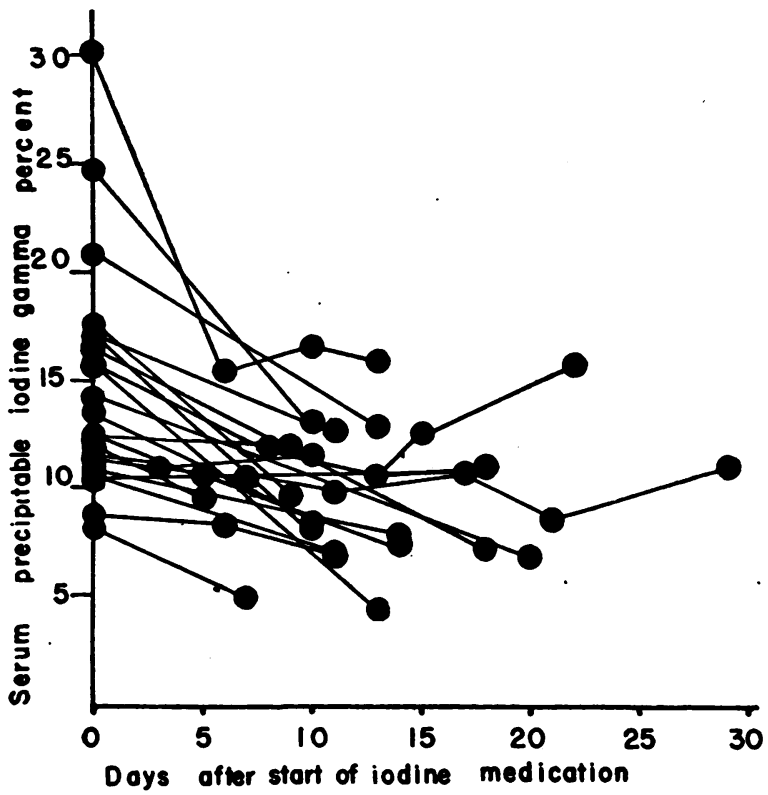

Fig. 1. Effects of Iodine Medication Alone (15 Drops Daily of Strong Solution of Iodine, USP) on the Serum Precipitable Iodine in 21 Cases of PreVIOUSLY UNTREATED HYPERTHYROIDISM

Serum precipitable iodine tended in many cases to fall, especially when the initial concentration was high, but occasionally was unaffected. Normal concentrations (3 to 8 gamma per cent) were reached only in a minority of cases. Data from 5 of these cases have been published elsewhere (1).

Since the basal metabolic rate was usually determined only once before treatment, these values recorded probably often exaggerated the true preoperative levels. Although this artifact was undoubtedly a factor tending to obscure a significant relationship, the dissociation between concentrations of serum iodine and of basal metabolic rate was often too gross to be readily attributable to this source. Also, high concentrations of iodine were not infrequently found in association with relatively slight elevations of the metabolic rate.

\section{Effects of iodine medication alone}

In Figure 1 are shown the results of iodine medication pre-operatively on the serum precipitable iodine of 21 previously untreated cases of hyperthyroidism. In general the concentrations tended to drop, especially in those cases in which it was initially rather high. In some instances, however, no distinct change occured. Within the second or third week period studied, the serum 


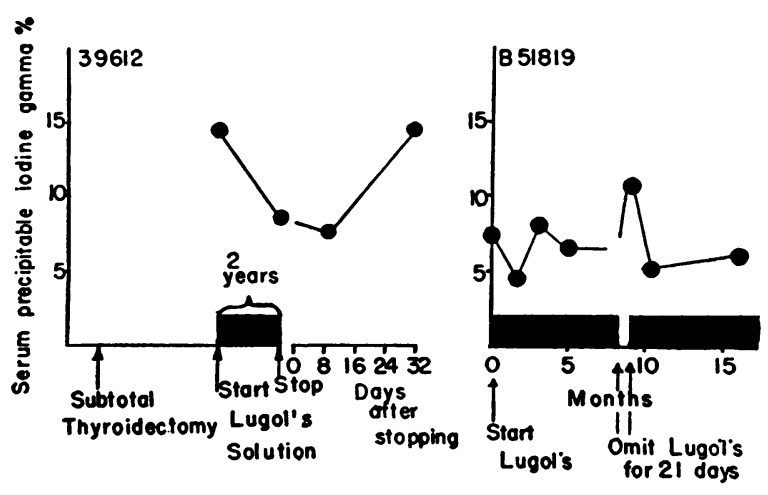

Fig. 2. Effects of Prolonged Iodine Medication (15 Drops Daily of Strong Solution of Iodine, USP) on the Serum Precipitable Iodine in 2 Cases of HyperTHYROIDISM

Partial (case 39612) or complete (case B51819) remission of hyperthyroidism was produced and maintained over many months by continued iodine medication, but interruption of iodine medication was promptly followed by a rise in serum precipitable iodine and clinical evidences of increased thyroid overactivity. Neither case, therefore, had become refractory or indifferent to iodine medication. Case 39612 was one of recurrent hyperthyroidism and subsequently underwent a second subtotal thyroidectomy; case B51819 has remained in complete remission with continued iodine medication after the brief interruption shown in the figure.

precipitable iodine occasionally fell to normal levels ( 3.0 to 8.0 gamma per cent), but more commonly remained somewhat elevated. Changes in basal metabolic rate paralleled those in the serum iodine; no distinct time lag could be detected.

Figure 2 illustrates the responses in two cases of hyperthyroidism in which iodine medication was continued for months and years. In the first case (39612), partial, in the second (B51819), complete remissions were maintained as long as the iodine medication was continued, but exacerbations of the hyperthyroidism promptly developed as soon as the iodine medication was discontinued.

\section{Effects of subtotal thyroidectomy}

(A) Immediate effects. In 4 cases the serum precipitable iodine was determined 3 hours after the conclusion of the operation and again at intervals during the next 2 weeks (Figure 3). After a slight rise on the day of operation the serum preciptable iodine fell, abruptly at first and then more slowly. Within 2 weeks the serum precipitable iodine of 1 patient (A42903) had already fallen below normal levels. No symptoms suggestive of myxedema were present in this case. Of the other 3 whose levels were nor$\mathrm{mal}$ at this time, 1 (A66295) developed subnormal values some weeks later along with clinical changes necessitating thyroid medication.

(B) Effects during the first half year. In Figure 4 all the serum iodine values obtained during the first 6 months following subtotal thyroidectomy are plotted against time. During the first 2 weeks supranormal values (above 8.0 gamma per cent) are common, but after this interval only one such value appears. This single high value was associated with a clinical recurrence of goiter and hyperthyroidism, the only one in this series to appear within the first 6 months. ${ }^{5}$ Subnormal values (below 3.0 gamma per cent) first appear at 14 days, then become and remain quite common after 3 weeks. Such abnormal values are only found in certain patients (about one quarter of the number studied), and are sometimes transient (Table 1).

(C) Effects after the first half year. In Figure 5 are collected all serum iodine values obtained in patients whose thyroidectomies had been done more than 6 months previously. In the group followed more than 5 years are included some cases in which the original operation had been done eleswhere years ago. Determinations of serum iodine after the first 6 months were usually obtained because of some clinical suspicion of overactivity or underactivity of the thyroid gland. Had all cases undergoing subtotal thyroidectomy here been called in and systematically examined, the proportion of normal values would doubtless have been greatly increased. Nevertheless Figure 5 does illustrate the frequency with which subnormal values for the serum iodine are found years after subtotal thyroidectomy. The cases having low concentrations of serum iodine in Figure 5 are analyzed more fully in Table I.

The occasional high values appearing in Figure 5 were all associated with clinical recurrence, usually mild, of hyperthyroidism. Seven recurrences developed before 5 years, 6 of which were so

5 This case was operated upon the first time by one of the residents early in his tenure, and there is some reason to believe that the procedure recommended was not carried out in its entirety. 


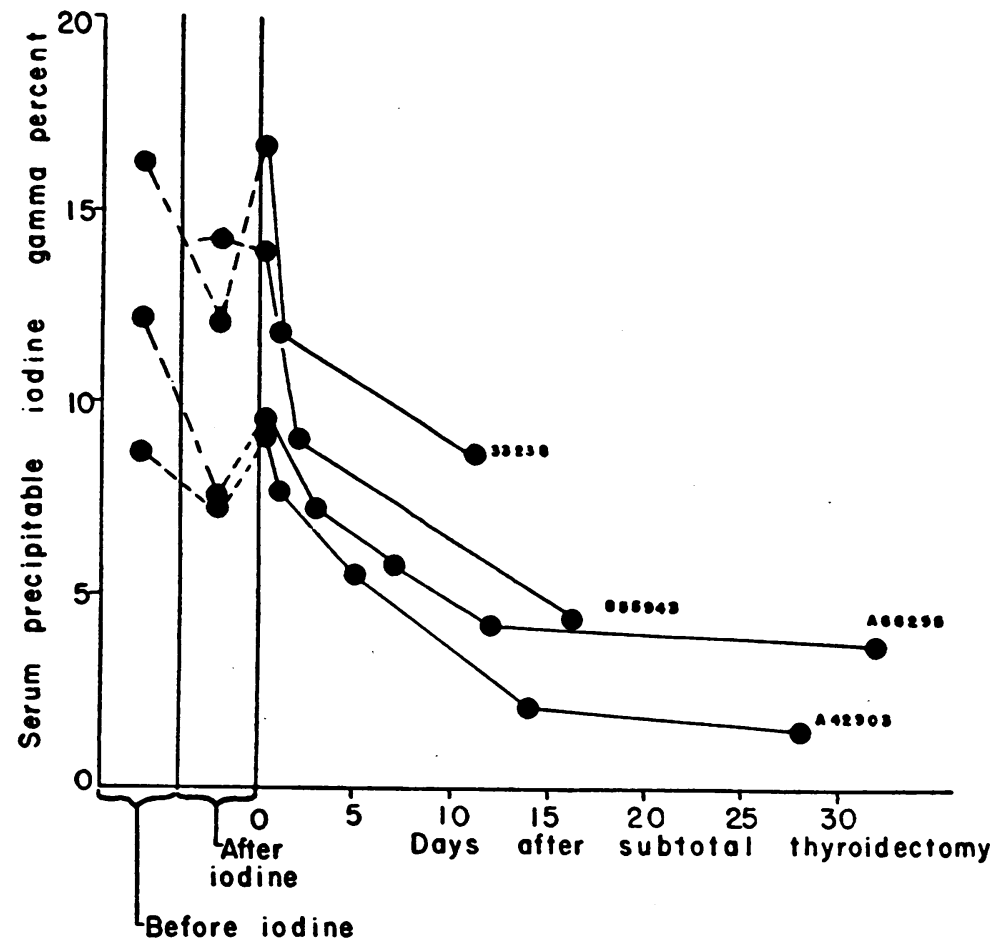

Fig. 3. Changes in the Serum Precipitable Iodine in 4 Cases of Hyperthyroidsm Immediately Following Subtotal Thyroidectomy

Fifteen drops daily of Strong solution of iodine, USP, had been given prior to operation but were discontinued on the day of operation. The first values obtained 3 hours after the completion of the operation are only slightly higher than the corresponding preoperative values. Iodine concentration fell during the next few days, abruptly at first and then more slowly. In one case (A42903) the concentration had become definitely subnormal within 2 weeks, and remained depressed for as long as the patient was followed without thyroid medication (several months). One other case (B55943) developed a subnormal level 3 to 4 months later; the other 2 (33238 and A66295) remained within normal limits as long as they were followed (Table 1).

mild that they could be controlled by iodine medication alone without operation. Only 1 case of this entire group operated on and followed since 1940 has required a second thyroidectomy, and only 2 cases of the approximately 130 cases operated on in the previous 5-year period (1935 to 1940) have required a second operation after 1940. The occasional high values obtained in the cases operated on here and elsewhere prior to 1940 illustrate the fact that the.disease may recur after a long interval of quiescence following subtotal thyroidectomy, or it may smolder for many years at levels of low intensity.

(D) Subnormal values in individual cases. These were found at some time or another after operation' in 33 patients. The time of develop- ment of these subnormal values and the associated changes in basal metabolic rate, serum cholesterol, and clinical status are all summarized in Table I (their general distribution has already been shown in Figures 4 and 5). In at least 3 instances (A45443, 95767; and B43492) the low values disappeared within 6 months. On the other hand, there were 14 cases in which low iodine values were present after more than a year, sometimes after many years, and 3 more cases ( $A 35428$, $B 22457$, and $A 42903$ ) in whom low values persisted for at least 9 months. It is impossible as yet to determine whether the remaining 13 cases are to be classed as permanent or transient. Twelve were followed for less than 10 months before thyroid therapy was commenced or the pa- 


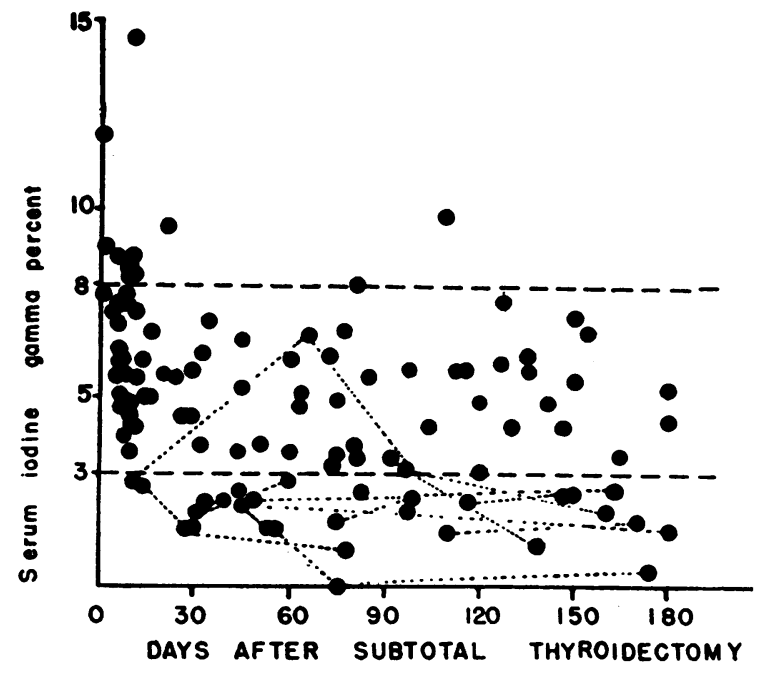

Fig. 4. Each Point Corresponds to One of 116 Individual Determinations of Serum Iodine in 60 Cases of Hyperthyroidism During the First 6 Months Following Subtotal Thyroidectomy

Dotted lines join repeated determinations of subnormal values in the same case. In the majority of cases the serum iodine concentration became and remained within normal limits after the first 2 weeks. High values were common during the first 10 to 15 days, and were only seen once after this interval. Subnormal values first appeared after 2 weeks and were frequently found after one month; many persisted throughout the entire period (Table 1).

tient disappeared from observation. The thirteenth case, B32017, maintained a level of serum iodine just about the lower limits of normal for about 2 years. Partial recovery of serum iodine levels soon after operation does not necessarily exclude later development of a chronic deficiency (B7257).

The basal metabolic rate in this group tended to be depressed, but in many instances a low level of serum iodine was associated with a basal metabolic rate which fell well within the normal range. For example, the minimum basal metabolic rate at the time of the low iodine fell below -30 per cent only twice; it fell between -30 and -20 per cent in 8 cases, and between -30 and -10 per cent in 12, it was -10 per cent or greater in 9 others (Table I). The serum cholesterol tended to be elevated, but exceptions were numerous. In the 24 cases studied, values exceeding $300 \mathrm{mgm}$. per cent were found in 13 instances, values below this level in the 11 others.
Sometimes the low levels of serum iodine were associated with outspoken clinical evidences of hypothyroidism, but more often this was not the case. The full-blown picture of sodden myxedema was rarely encountered. Necessarily, the rating of severity of the clinical signs and symptoms of hypothyroidism as $0,1+, 2+$, and $3+$ in Table I is only the roughest sort of estimate. A rating of $1+$ means simply minimal signs of thyroid deficiency, such as excessive weight gain; a diagnosis of hypothyroidism would hardly have been suggested except for the history of a subtotal thyroidectomy. A $2+$ rating means minimal changes only in the facies or skin, and a fairly distinct response to thyroid medication. All cases with unmistakable facies, voice and hair changes, and psychomotor retardation were classed as $3+$. Only 5 cases exhibited changes marked enough to be classed as $3+$. In 10 of the 33 cases the clinical evidences of hypothyroidism never became more intense than $2+$, and in 13 more never exceeded $1+$. In 5 cases no clinical evidence at all of hypothyroidism could be detected. Almost all the cases rated as $1+$ or more improved markedly in their sense of well being and experi-

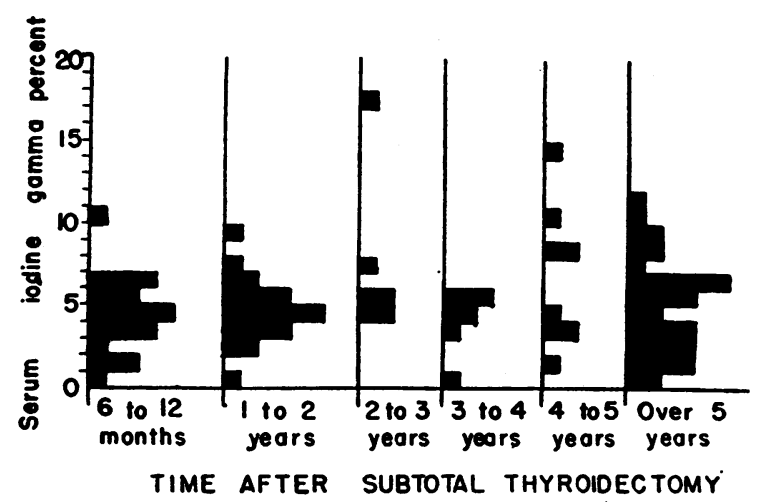

Fig. 5. Each Small Square Corresponds to One of 97 Determinations of Serum Iodine Made More than 6 Months After Subtotal Thyroidectomy in 83 Cases OF HYPERTH YROIDISM

These determinations were usually made only in those cases in which there was clinical suspicion of hyperthyroidism or hypothyroidism, so that the proportion of abnormal values is undoubtedly much higher than would have been the case had all the patients been represented. The figure indicates, however, both the occasional recurrence of high values long after the initial operation, and the considerable number of cases with low values years after the operation (Table 1). 
enced a sharp drop in the body weight with thyroid medication in doses not exceeding 0.06 grams daily. This is evidence that they were truly suffering from a state of partial thyroid deficiency, even though initially they were subjectively unaware of any disturbance.

\section{DISCUSSION}

It is commonly believed that subtotal thyroidectomy effects a complete and lasting cure of hyperthyroidism in the great majority of patients (11). The rarity of supranormal values of the serum iodine during the months and years follow- ing subtotal thyroidectomy supports this view. It is also, however, generally held that permanent hypothyroidism following subtotal thyroidectomy is a rare occurence, much rarer, in fact, than recurrence of hyperthyroidism $(12,13)$. This latter belief may be seriously questioned in view of the considerable number of instances in which low values of the serum iodine are found long after the operation. The immediate sequel of operation in this series seems to have been hypothyroidism in many cases. Subsequently this disappeared in some cases while in others it persisted. Presumably this difference in behavior depended on dif-

TABLE I

Serum iodine, basal metabolic rate, and serum cholesterol at different intervals following subtotal thyroidectomy. All patients in whom the concentration of iodine in serum fell below 3.0 gamma per cent at any time after operation are included. Values obtained during or soon after a course of thyroid medication are omitted.

\begin{tabular}{|c|c|c|c|c|c|c|c|c|c|c|c|}
\hline $\begin{array}{l}\text { Number. } \\
\text { Age in years. } \\
\text { Sex }\end{array}$ & $\begin{array}{c}\text { Time } \\
\text { after } \\
\text { opera- } \\
\text { tion }\end{array}$ & $\begin{array}{c}\text { Serum } \\
\text { iodine } \\
\text { concen- } \\
\text { tration† }\end{array}$ & BMR & $\begin{array}{l}\text { Serum } \\
\text { choles- } \\
\text { terol }\end{array}$ & $\begin{array}{c}\text { Clinical } \\
\text { hypo- } \\
\text { thyroid- } \\
\text { ism }\end{array}$ & $\begin{array}{l}\text { Number. } \\
\text { Age in years. } \\
\text { Sex }\end{array}$ & $\begin{array}{l}\text { Time } \\
\text { after } \\
\text { opera- } \\
\text { tion }\end{array}$ & $\begin{array}{c}\text { Serum } \\
\text { iodine } \\
\text { concen- } \\
\text { tration† }\end{array}$ & BMR & $\begin{array}{c}\text { Serum } \\
\text { choles- } \\
\text { terol }\end{array}$ & $\begin{array}{c}\text { Clinical } \\
\text { hypo- } \\
\text { thyroid- } \\
\text { ism }\end{array}$ \\
\hline $\begin{array}{l}\mathrm{A} 45443 \\
46 \mathrm{~F}\end{array}$ & $\begin{array}{c}\text { months } \\
2 \\
5 \\
\end{array}$ & $\begin{array}{c}\underset{\text { gamma }}{\text { per cent }} \\
2.4 \\
6.7 \\
\end{array}$ & $\begin{array}{c}\text { per cent } \\
\text { normal } \\
+8 \\
-1 \\
\end{array}$ & $\begin{array}{l}\text { mer cent } \\
\text { per cent }\end{array}$ & $\begin{array}{l}0 \\
0 \\
\end{array}$ & $\begin{array}{l}65313 \\
19 \mathrm{~F} \\
\end{array}$ & $\begin{array}{c}\text { months } \\
7 \\
9 \\
\end{array}$ & $\begin{array}{r}\text { gamma } \\
\text { per cent } \\
3.0^{* *} \\
2.7^{* *} \\
\end{array}$ & $\begin{array}{c}\text { per cent } \\
\text { normal } \\
-22 \\
-20 \\
\end{array}$ & $\begin{array}{c}\underset{\text { per cent }}{\text { per }} \\
273 \\
210 \\
\end{array}$ & $\begin{array}{l}1+ \\
2+\end{array}$ \\
\hline \multirow[t]{2}{*}{$\begin{array}{l}95767 \\
13 \mathrm{~F}\end{array}$} & \multirow{2}{*}{$\begin{array}{r}0 \\
1 \\
3 \\
4 \\
5 \\
6 \\
18 \\
21\end{array}$} & \multirow{2}{*}{$\begin{array}{l}3.6 \\
3.8^{*} \\
2.3 \\
2.4 \\
4.8 \\
6.5 \\
4.7 \\
4.9\end{array}$} & \multirow{2}{*}{$\begin{array}{l}-13 \\
-16 \\
-13 \\
-13 \\
-19 \\
-3 \\
-7 \\
-3\end{array}$} & & \multirow{2}{*}{$\begin{array}{l}0 \\
1+ \\
0 \\
0 \\
0 \\
0 \\
0 \\
0\end{array}$} & $\begin{array}{l}\text { A22701 } \\
53 \mathrm{~F}\end{array}$ & $\begin{array}{r}2 \\
14 \\
\end{array}$ & $\begin{array}{l}3.8 \\
2.1 \\
\end{array}$ & $\begin{array}{l}-4 \\
-6 \\
\end{array}$ & & $\begin{array}{l}1+ \\
2+\end{array}$ \\
\hline & & & & & & $\begin{array}{c}\mathrm{A} 92514 \\
55 \mathrm{~F}\end{array}$ & $\begin{array}{r}0 \\
3 \\
38 \\
41 \\
\end{array}$ & $\begin{array}{l}4.9 \\
2.0^{*} \\
0.5 \\
1.4 \\
\end{array}$ & $\begin{array}{r}+1 \\
+8 \\
-10 \\
\end{array}$ & 415 & $\begin{array}{l}0 \\
0 \\
2+ \\
2+ \\
\end{array}$ \\
\hline \multirow[t]{2}{*}{$\begin{array}{l}\text { B43492 } \\
32 \mathrm{~F}\end{array}$} & \multirow{2}{*}{$\begin{array}{r}0 \\
3 \\
4 \\
6 \\
7 \\
12\end{array}$} & \multirow{2}{*}{$\begin{array}{l}5.0 \\
2.5 \\
5.9 \\
3.4 \\
3.8 \\
4.1\end{array}$} & \multirow{2}{*}{$\begin{array}{r}-2 \\
-21 \\
-19 \\
-12 \\
-15 \\
-2 \\
\end{array}$} & \multirow{2}{*}{$\begin{array}{l}295 \\
247 \\
254 \\
262 \\
212\end{array}$} & \multirow{2}{*}{$\begin{array}{l}0 \\
0 \\
1+ \\
1+ \\
1+ \\
1+\end{array}$} & $\begin{array}{c}\text { A39971 } \\
38 \mathrm{~F}\end{array}$ & $\begin{array}{r}2 \\
3 \\
20\end{array}$ & $\begin{array}{l}1.8^{*} \\
2.4^{*} \\
2.7\end{array}$ & $\begin{array}{l}-21 \\
-21 \\
-31\end{array}$ & $\begin{array}{l}226 \\
244\end{array}$ & $\begin{array}{l}1+ \\
2+ \\
2+\end{array}$ \\
\hline & & & & & & \multirow[t]{2}{*}{$\begin{array}{c}\text { B7257 } \\
16 \mathrm{~F}\end{array}$} & \multirow{2}{*}{$\begin{array}{r}4 \\
6 \\
27 \\
45 \\
50 \\
55\end{array}$} & \multirow{2}{*}{$\begin{array}{l}1.3^{* *} \\
1.8 \\
2.0 \\
3.8 \\
3.1^{*} \\
1.8\end{array}$} & \multirow{2}{*}{$\begin{array}{r}-15 \\
-10 \\
-10 \\
+4 \\
-1 \\
-14\end{array}$} & \multirow[t]{2}{*}{300} & \multirow{2}{*}{$\begin{array}{l}1+ \\
1+ \\
1+ \\
0 \\
0 \\
1+\end{array}$} \\
\hline $\begin{array}{c}\text { B6138 } \\
41 \mathrm{~F}\end{array}$ & 5 & $2.5^{* *}$ & -7 & 245 & 0 & & & & & & \\
\hline $\begin{array}{l}\text { B32017 } \\
21 \mathrm{~F}\end{array}$ & $\begin{array}{r}1 \\
2 \\
19 \\
20 \\
21\end{array}$ & $\begin{array}{l}2.1^{*} \\
1.6^{*} \\
3.2^{*} \\
3.0 \\
4.3\end{array}$ & $\begin{array}{r}-2 \\
-17 \\
-20 \\
-17 \\
-14\end{array}$ & $\begin{array}{l}381 \\
376 \\
\\
325\end{array}$ & $\begin{array}{l}1+ \\
2+ \\
0 \\
0 \\
0\end{array}$ & $\begin{array}{c}\mathrm{A} 42903 \\
30 \mathrm{~F}\end{array}$ & $\begin{array}{r}0 \\
1 \\
1 \\
3 \\
9 \\
11\end{array}$ & $\begin{array}{l}5.6 \\
2.7 \\
1.5 \\
1.0 \\
1.7 \\
1.1\end{array}$ & $\begin{array}{l}-4 \\
-8 \\
-2\end{array}$ & 468 & $\begin{array}{l}\mathbf{0} \\
\mathbf{0} \\
\mathbf{0} \\
\mathbf{0} \\
\mathbf{0} \\
\mathbf{0}\end{array}$ \\
\hline $\begin{array}{l}10184 \\
42 \mathrm{M}\end{array}$ & $\begin{array}{l}1 \\
2\end{array}$ & $\begin{array}{l}2.0^{* *} \\
2.7^{* *}\end{array}$ & -2 & 325 & $\begin{array}{l}1+ \\
1+\end{array}$ & \multirow{3}{*}{$\begin{array}{r}625 \\
40 \mathrm{~F}\end{array}$} & \multirow{3}{*}{$\begin{array}{l}60 \\
61 \\
62 \\
63 \\
68 \\
70 \\
71 \\
72\end{array}$} & \multirow{3}{*}{$\begin{array}{l}2.2^{* * *} \\
2.5^{* *} \\
3.8^{* *} \\
2.2^{* *} \\
2.8 \\
4.1 \\
2.2 \\
3.7\end{array}$} & \multirow{3}{*}{$\begin{array}{r}-14 \\
-1 \\
+14 \\
-14 \\
-12 \\
-11 \\
-17\end{array}$} & \multirow{3}{*}{$\begin{array}{l}216 \\
178 \\
174\end{array}$} & $1+$ \\
\hline $\begin{array}{c}\text { B59454 } \\
40 \mathrm{~F}\end{array}$ & $\begin{array}{l}2 \\
5 \\
8 \\
\end{array}$ & $\begin{array}{l}2.3 \\
2.6 \\
1.7 \\
\end{array}$ & $\begin{array}{r}-9 \\
-7 \\
-11 \\
\end{array}$ & $\begin{array}{l}195 \\
183 \\
\end{array}$ & $\begin{array}{l}0 \\
1+ \\
2+ \\
\end{array}$ & & & & & & $\begin{array}{l}1+ \\
1+ \\
1+\end{array}$ \\
\hline $\begin{array}{c}\text { B60788 } \\
50 \mathrm{~F}\end{array}$ & $\begin{array}{l}2 \\
4 \\
8\end{array}$ & $\begin{array}{l}1.5 \\
0.0 \\
0.4\end{array}$ & $\begin{array}{l}+7 \\
-5 \\
+3\end{array}$ & $\begin{array}{l}373 \\
369\end{array}$ & $\begin{array}{l}1+ \\
2+ \\
2+\end{array}$ & & & & & & $1+$ \\
\hline$\underset{63 \mathrm{~F}}{\mathrm{~A} 35428}$ & $\begin{array}{l}10 \\
10\end{array}$ & $\begin{array}{l}3.1 \\
1.3\end{array}$ & -19 & 290 & $\begin{array}{l}2+ \\
2+\end{array}$ & $\begin{array}{l}54183 \\
15 \mathrm{~F}\end{array}$ & $\begin{array}{l}108 \\
144 \\
156\end{array}$ & $\begin{array}{l}2.8^{* *} \\
2.5 \\
2.4\end{array}$ & $\begin{array}{l}-22 \\
-19 \\
-14\end{array}$ & $\begin{array}{l}453 \\
514\end{array}$ & $\begin{array}{l}1+ \\
1+ \\
1+\end{array}$ \\
\hline
\end{tabular}


TABLE I-Continued

\begin{tabular}{|c|c|c|c|c|c|c|c|c|c|c|c|}
\hline $\begin{array}{l}\text { Number. } \\
\text { Age in years. } \\
\text { Sex }\end{array}$ & $\begin{array}{c}\text { Time } \\
\text { after } \\
\text { opera- } \\
\text { tion }\end{array}$ & $\begin{array}{c}\text { Serum } \\
\text { iodine } \\
\text { concen- } \\
\text { tration† }\end{array}$ & BMR & $\begin{array}{c}\text { Serum } \\
\text { choles- } \\
\text { terol }\end{array}$ & $\begin{array}{c}\text { Clinical } \\
\text { hypo- } \\
\text { thyroid- } \\
\text { ism }\end{array}$ & $\begin{array}{l}\text { Number. } \\
\text { Age in years. } \\
\text { Sex }\end{array}$ & $\begin{array}{c}\text { Time } \\
\text { after } \\
\text { opera- } \\
\text { tion }\end{array}$ & $\begin{array}{c}\text { Serum } \\
\text { iodine } \\
\text { concen- } \\
\text { tration } \dagger\end{array}$ & BMR & $\begin{array}{c}\text { Serum } \\
\text { choles- } \\
\text { terol }\end{array}$ & $\begin{array}{c}\text { Clinical } \\
\text { hypo- } \\
\text { thyroid- } \\
\text { ism }\end{array}$ \\
\hline $\begin{array}{l}33751 \\
57 \mathrm{~F}\end{array}$ & $\begin{array}{c}\text { months } \\
2 \\
3 \\
5\end{array}$ & $\begin{array}{c}\underset{\text { gammar cent }}{\text { per }} \\
6.4^{*} \\
3.2\end{array}$ & $\begin{array}{c}\text { per cent } \\
\text { normal } \\
+23 \\
+49\end{array}$ & $\underset{\text { per cent }}{m g m .}$ & $\begin{array}{l}0 \\
0\end{array}$ & $\mathrm{~A}_{38 \mathrm{~F}}^{\mathrm{A} 52638}$ & $\begin{array}{c}\text { months } \\
72\end{array}$ & $\begin{array}{c}\begin{array}{c}\text { gamma } \\
\text { per cent } \\
1.3\end{array} \\
\end{array}$ & $\begin{array}{c}\text { per cent } \\
\text { normal } \\
-27\end{array}$ & $\begin{array}{c}\underset{\text { per cent }}{m g m .} \\
270\end{array}$ & $1+$ \\
\hline $\begin{array}{c}\text { B30951 } \\
59 \mathrm{~F}\end{array}$ & $\begin{array}{l}2 \\
5\end{array}$ & $\begin{array}{l}2.1^{*} \\
3.0^{*}\end{array}$ & -30 & 256 & $\begin{array}{l}0 \\
1+\end{array}$ & $\begin{array}{c}97827 \\
58 \mathrm{~F}\end{array}$ & $\begin{array}{l}300 \\
300 \\
301\end{array}$ & $\begin{array}{l}2.5 \\
3.2 \\
2.9\end{array}$ & $\begin{array}{r}+3 \\
-11\end{array}$ & $\begin{array}{l}280 \\
346\end{array}$ & $\begin{array}{l}1+ \\
1+ \\
1+\end{array}$ \\
\hline$-\underset{35 \mathrm{M}}{\mathrm{B} 22457}$ & 11 & $0.6^{*}$ & -23 & & $2+$ & $\underset{65 \mathrm{~F}}{\mathrm{~A} 45359}$ & $\begin{array}{l}60 \\
63\end{array}$ & $\begin{array}{l}1.5^{* *} \\
1.0^{* *}\end{array}$ & $\begin{array}{l}-12 \\
-16\end{array}$ & $\begin{array}{l}319 \\
450\end{array}$ & $1+$ \\
\hline $\begin{array}{l}\text { A89359 } \\
50 \mathrm{~F}\end{array}$ & 2 & $2.3^{*}$ & & & $2+$ & $\begin{array}{c}\text { B23293 } \\
64 \mathrm{~F}\end{array}$ & 60 & 0.6 & -36 & 323 & $3+$ \\
\hline \multirow[t]{2}{*}{$\begin{array}{c}\text { B55943 } \\
38 \mathrm{~F}\end{array}$} & \multirow{2}{*}{$\begin{array}{l}1 \\
3 \\
5 \\
6 \\
\end{array}$} & \multirow[t]{2}{*}{$\begin{array}{l}5.0 \\
3.3 \\
1.1\end{array}$} & \multirow[b]{2}{*}{-16} & & \multirow{2}{*}{$\begin{array}{l}0 \\
1+ \\
2+ \\
3+\end{array}$} & $\begin{array}{l}\text { A48201 } \\
60 \mathrm{~F}\end{array}$ & 120 & 1.3 & -10 & 383 & $3+$ \\
\hline & & & & & & $\begin{array}{l}35565 \\
42 \mathrm{~F}\end{array}$ & 228 & 1.6 & -26 & 776 & $3+$ \\
\hline $\begin{array}{l}\text { B37483 } \\
36 \mathrm{M}\end{array}$ & $\begin{array}{l}0 \\
1 \\
6\end{array}$ & $\begin{array}{l}4.3 \\
2.2 \\
1.7^{*} \\
\end{array}$ & $\begin{array}{r}-4 \\
+1 \\
-12 \\
\end{array}$ & & $\begin{array}{l}0 \\
1+ \\
1+\end{array}$ & $\begin{array}{l}\text { B58925 } \\
66 \mathrm{~F}\end{array}$ & 60 & 0.7 & -25 & 447 & $3+$ \\
\hline $\begin{array}{c}\text { B69052 } \\
45 \mathrm{~F}\end{array}$ & 3 & 2.3 & & 225 & $1+$ & \multirow[t]{2}{*}{$\begin{array}{l}99644 \\
30 \mathrm{~F}\end{array}$} & \multirow[t]{2}{*}{72} & \multirow[t]{2}{*}{$2.9^{* *}$} & \multirow[t]{2}{*}{-16} & \multirow[t]{2}{*}{221} & \multirow[t]{2}{*}{0} \\
\hline $\begin{array}{l}72671 \\
44 \mathrm{~F}\end{array}$ & 1 & 1.6 & -18 & & $1+$ & & & & & & \\
\hline
\end{tabular}

ferences in the ability of the remnant of gland left at operation to regenerate properly. This in turn must be conditioned by the radicalism of the operation. The low incidence of recurrent hyperthyroidism and the high incidence of hypothyroidism in the cases whose operations were performed in this hospital during the past 5 years contrasts with the higher incidence of recurrences after operations in this hospital 15 years ago. The difference can readily be explained by the increased radicalism in surgical technique.

It is also quite possible that persistent hypothyroidism was somewhat more common in the past than was recognized at the time. The number of cases in this series of low serum iodine following thyroidectomy performed years earlier is evidence to the point. Before the introduction of the serum iodine technique, diagnosis depended on clinical signs, on the basal metabolism, and on the serum cholesterol. Since postoperative hypothyroidism is, more often than not, partial and clinically equivocal, all of these less sensitive indications may well fall within normal limits (Table I), thus rendering recognition difficult.

These considerations are all based on the assumption that a low concentration of serum iodine means a low level of output of hormone by the thyroid gland. This in turn is based on the findings in clinical myxedema, in which a low concentration of iodine in serum was invariably found (7), and upon a study of the serum iodine in a series of several hundred subjects without hyperthyroidism in whom a low iodine concentration was never found (9). On the whole, the internal evidence in this study confirms this interpretation of a depression of serum iodine, since most of the subjects had other evidences of thyroid deficiency and responded clinically to thyroid medication. As in spontaneous myxedema, serum iodine rose to normal levels with thyroid therapy in doses ranging from 0.06 to 0.12 grams of dried thyroid daily.

The fall, after iodine medication, of the serum precipitable iodine from a previously elevated level in untreated hyperthyroidism confirms the 
observations of others $(2,3)$. A greater variability was found in response to iodine, both acutely and chronically, than has sometimes been described. Not only may the remission be complete initially but it may sometimes persist for long periods. Iodine medication may even occasionally effect an actual cure. The behavior of the serum precipitable iodine in the 2 subjects of Figure 2 lends support to the theory of Means and others that patients need not become refractory to iodine and that at all times iodine medication exerts some restraining effect on the release of hormone by the hyperthyroid gland.

These observations were not made at sufficiently close intervals to demonstrate clearly a lag in the fall of the basal metabolism behind that of the serum iodine prior to operation, although this was suggested in some individual cases. Postoperatively, the serum iodine often fell to subnormal levels without any further consistent drop in the basal metabolic rate, so that the correlation between the two was poor. The metabolic rate behaved as if, even with sharp decline in serum iodine, an inadequate output of hormone often sufficed to keep it within normal limits.

There are certain clinical implications of these observations. A partial type of hypothyroidism may develop as a sequel to subtotal thyroidectomy, and may often become permanent. It is characterized by mild symptoms of thyroid deficiency and a low serum iodine; basal metabolism is frequently within normal limits and serum cholesterol often only slightly elevated. It may therefore escape detection if these latter measurements are relied on for diagnosis. More severe grades of hypothyroidism may develop, either within a few months or after a delay of some years. Practically, it is obvious from Table I that a basal metabolic rate falling within normal limits is no evidence that thyroid function is adequate.

These findings should not be interpreted as a plea for less radical removal of the gland in subtotal thyroidectomy. The radical operation recommended has fully justified itself in the very low incidence of recurrent hyperthyroidism in this series. Between the Scylla of recurrences and the Charybdis of permanent hypothyroidism, the latter is the lesser evil. The fact that one or the other seems bound to occur in a certain number of cases fol- lowing subtotal thyroidectomy must, however, be weighed along with the other drawbacks associated with this operation in deciding on the relative merits of operative intervention or more prolonged medical therapy in hyperthyroidism.

\section{CONCLUSIONS}

1. The range of values of the serum precipitable iodine in untreated hyperthyroidism is defined. Ninety-five per cent of the values fell above 8 gamma per cent. If the 2 cases who were probably in spontaneous remission are excluded, 98 per cent of the values fell above 8 gamma per cent.

2. The serum precipitable iodine sometimes, but not always, declined with iodine medication in hyperthyroidism, but only attained normal levels in a certain number of cases. Even when given for long periods it continued to exert a depressing effect on the serum precipitable iodine.

3. Subtotal thyroidectomy was followed within 3 hours by a slight rise in serum precipitable iodine, not exceeding a few gamma per cent. Serum precipitable iodine then fell steadily, so that within 3 weeks all supranormal values had disappeared. Later elevations were rare.

4. Subnormal values of the serum iodine might develop within 2 weeks following subtotal thyroidectomy. Although this depression was sometimes transient, these low values in some cases persisted indefinitely.

5. Subnormal values are usually associated with some clinical evidence of mild thyroid deficiency, but the basal metabolism was often within normal limits and the serum cholesterol only slightly elevated. It is probable that low concentrations of precipitable iodine indicate a mild form of partial hypothyroidism. Low serum iodine values are common enough months after subtotal thyroidectomy to indicate that chronic partial hypothyroidism is a not uncommon sequel of subtotal thyroidectomy.

6. The clinical implications of these findings are discussed.

\section{BIBLIOGRAPHY}

1. Lowenstein, B. E., Bruger, M., and Hinton, J. W., The protein-bound plasma iodine in patients with thyroid disease. I. Correlation with basal heat production. J. Clin. Endocrinol., 1944, 4, 268. 
2. Lowenstein, B. E., Bruger, M., Hinton, J. W., and Lough, W. G., The protein-bound iodine in patients with thyroid disease. J. Clin. Endocrinol., 1945, 5, 181.

3. Man, E. B., Smirnow, A. E., Gildea, E. F., and Peters; J. P., Serum iodine fractions in hyperthyroidism. J. Clin. Invest., 1942, 21, 773.

4. Riggs, D. S., Gildea, E. F., Man, E. B., and Peters, J. P., Blood iodine in patients with thyroid disease. J. Clin. Invest., 1941, 20, 345.

5. Riggs, D. S., Lavietes, P. H., and Man, E. B., Investigations on the nature of blood iodine. J. Biol. Chem., 1942, 143, 363.

6. Salter, W. T., Bassett, A. M., and Sappington, T. S., Protein-bound iodine in blood. II. Its relation to thyroid function in 100 clinical cases. Am. J. M. Sc., 1941, 202, 527.

7. Winkler, A. W., Riggs, D. S., and Man, E. B., Serum iodine in hypothyroidism before and during thyroid therapy. J. Clin. Invest., 1945, 24, 722.

8. Riggs, D. S., and Man, E. B., A permanganate acid ashing micromethod for iodine determinations. I. Values in blood of normal subjects. J. Biol. Chem., 1940, 134, 193.

9. Man, E. B., and Winkler, A. W., Unpublished data.

10. Peters, J. P., and Man, E. B., The interrelations of serum lipids in patients with thyroid disease. J. Clin. Invest., 1943, 22, 715.

11. Means, J. H., The Thyroid and Its Diseases. J. B. Lippincott Co., Philadelphia, 1937.

12. Thompson, W. O., and Thompson, P. K., Low basal metabolism following thyrotoxicosis. I. Temporary type without myxedema, with special reference to the rôle of iodine therapy. J. Clin. Invest., 1928, $5,441$.

13. Winkler, A. W., Hypometabolism following subtotal thyroidectomy. Internat. Clin., 1941, 1, 255. 